\title{
PROBLEMS OF TRANSPORT COMPLEX STAFFING OF UKRAINIAN SSR IN 1960-1980
}

\author{
Anatoliy GORBAN ${ }^{1}$ \\ Kyiv State Maritime Academy named After Hetman Petro Konashevich Sahaydachnyi, Ukraine
}

\begin{abstract}
In the article the staffing problems of transport complex in the period of its fundamental technical change and intensive development of 1960-1980-ies are described. The main purpose of this article is to analyze the peculiarities of personnel potential development of transport complex of the Ukrainian SSR in the years of the intensive development of transport sectors, figure out the social component of the measures to improve the efficiency of transport networks. Methodology. In this article we used the method of analysis. The qualitative personnel structure, training of skilled workers in the educational institutions and other forms of improvement of personal skills of transport workers are analyzed. The causes of staff turnover and low labour discipline are studied. Practical implementation. This article shows the possible opportunities for the modern transport complex of Ukraine, how to be successful and competitive in the market. The historical background of this article can be very useful for present managers of the transport complex. Results. The author makes a general conclusion that the main causes of personnel fluctuation in transport brunches are low wages, pour conditions of work and lack of accomodations for the staff. The social and practical measures to improve effectiveness of work with personnel of all brunches of transport system are characterized.
\end{abstract}

Key words: transport complex, different kinds of transport, providing staff, training of skilled workers, staff turnover, improve effectiveness.

JEL Classification: A10, A13, L23

\section{Introduction}

Fulfillment of the tasks of efficiency increase of the transport complex work of the Ukrainian SSR on the basis of radical technical reconstruction of all transport industries in the 1960-1980-ies crucially depended on the solution of personnel problems. Training of qualified specialists for transport sectors at higher and secondary professional schools and other educational institutions with various forms of training didn't solve the problem and staff turnover remained high. The main reasons of it were low wages, poor conditions of work and life and lack of housing. This situation caused the search of ways to increase efficiency of work with personnel of all parts of the transport system. The closeness of these problems to the modern ones actualizes the necessity of a comprehensive study of the experience of these problems' solving to use this experience in modern conditions.

\section{Analysis of researches and publications}

The problem of staffing sectors of the transport complex of the Ukrainian SSR in 1960-1980-ies, their social and material security remained outside the attention of researchers of the Soviet period. In the publications devoted to the development of transport main attention was focused on the coverage of positive dynamics of the transportation work. Only recently there appeared a research of S. Lesyk, where the author describes the training and the usage of qualified engineer-technical staff of railway transport, including several aspects of social and material supply of the personnel (Lesyk, 2013).

\section{Statistical indicators of transport complex}

At the beginning of 1960 -ies the number of specialists with higher and secondary special education for transport organizations increased markedly. So, in 1965 76,1 thousand people with higher and secondary special education worked on the transport but in 1957 only 28.9 thousand people worked in this sector. Annually the higher educational institutions of the Republic produced about 5 thousand specialists for the transport sector, and secondary professional schools prepared more than 10 thousand specialists (National economy in USSR, 1966). Totally, in 1965 more than 1.3 million people worked in the transport sector. Each year the number of employees in transportation industries was growing, as it is evidenced by the data (table 1) (Olsen, 2003).

\footnotetext{
Corresponding author:

${ }^{1}$ Department of Humanities, Kyiv State Maritime Academy named After Hetman Petro Konashevich Sahaydachnyi.

E-mail: ekaterinagoroshko@mail.ru
} 
Table 1

Dynamics of the growth of number of workers and employees of the transport complex in Ukraine (by sectors, in \% by 1940)

\begin{tabular}{|l|c|c|c|}
\hline & 1965 & 1970 & 1975 \\
\hline Kind of transport & 197 & 225 & 255 \\
\hline Railways & 118 & 119 & 132 \\
\hline Water & 311 & 397 & 445 \\
\hline Automobile & 288 & 345 & 395 \\
\hline Totally in the national economy & 204 & 248 & 279 \\
\hline
\end{tabular}

In the 1970s more than 1.5 million people worked at transport organizations. (National economy in USSR, 1971). The average monthly wage of employees in various transport sectors was a little higher than the average for the national economy (table 2) (Olsen, 2003).

Development of transport system mostly depended on the stability and coherence of the railway transport, which entered a period of technical upgrade and reconstruction. Technical school of locomotive operators played an important role while staffing the transfer of the Railways to diesel and electric traction. They were created in 1956 by joining and reorganization of the road schools and schools of locomotive operators with a three-year study (History of rail transport in the Soviet Union, 1970). The best among them were Lviv technical school of Lviv Railway, Kharkiv technical school of Southern Railway (Central State Arheve of Higher Organs of Power and Management, 1970).

The process of training was complicated by the reasons of objective and subjective character. Thus, workers often did not want to go for re-training because during full day time training they usually were not provided with accomodation for the period of training. For example, a hostel of the technical school of railway transport in Kiev could provide accommodation only for 19 students of an educational consulting office for training, and remaining 80 learners had to settle on their own, which created additional inconvenience (Central State Arheve of Higher Organs of Power and Management, 1970).

One of the forms of re-training became «schools of excellence» in departments of Railways, which became widespread in the 1960-ies. About 4 thousand people were annually trained there (National economy in USSR, 1971). The training was facilitated by an extensive network of library collections. In 1960-ies, road scientific-technical library had more than 92 thousand books, and network libraries had 667 thousand books.
There were not enough workers with higher and secondary special education. In 1984 the need for specialists with higher education in «Ukrzalizprom» was granted only to $40 \%$, with secondary special education to $49 \%$. There was high turnover of staff. In 1984 the company «Ukrzaliztrans» recruited 2232 people and dismissed 2167 people (without internal displacement) including 1188 resigned people on their own desire and 228 people were fired for truancy and violations of labour discipline (Lesyk, 2013). In 1987 the association employed 1900 people and 2295 were dismissed including 1094 people on their own desire and 194 people for violation of labor discipline (Lesyk, 2013). The main reasons of high turnover of staff in the association «Ukrzaliztrans» as well as throughout the industry there were working conditions, low wages and poor living conditions, especially the housing problem. The resignation in most of the cases occurred in connection with dissatisfaction with the profession $(20 \%)$, including $35 \%$ of loaders and $25 \%$ of shunters, $17.5 \%$ of the dismissed ones were not satisfied with the salary, $13,5 \%$ resigned because of heavy physical labour. The highest turnover rate was observed among technicians for repair of locomotives, it was $20.4 \%$ (Lesyk, 2013).

The rate of wages of station shunters, road workers, weighers, fitters of points of technical inspection was extremely low (Olsen, Osmundsen, 2003). Among women the reasons of the resignation were poor conditions of work, transfer to the place of work closer to the residence, low wages, lack of kindergardens and absence of accommodation (National economy in USSR, 1971). Wages of workers of urban and regional enterprises with the same qualifications were $10-15 \%$ higher than that of the workers of enterprises of railway transport. For example, in 1966 at the station Tiotkino of South-Western railway the station master received a salary of 130 rubles and the head of the transport department from the neighboring sugar factory was 150 rubles (Olsen, Osmundsen, 2003).

Measures to solve the housing problem used by the railway department were not enough. Therefore, at the expense of funds of enterprises in an economic way the construction of houses was carried out, loans and building materials to individual developers were given out. In particular, in 1962 in the South-Western railway 1598 workers were provided with accommodation, however, more than 5 thousand workers were in need of housing (National economy in USSR, 1985).

Table 2

Average monthly salary of employees in transport (by industry in 1965-1984 years (in rubles)

\begin{tabular}{|l|c|c|c|c|c|}
\hline & 1965 & 1970 & 1975 & 1980 & 1984 \\
\hline Kind of transport & 95,6 & 120,9 & 147,4 & 168,2 & 182,1 \\
\hline Railways & 91,4 & 112,5 & 142,5 & 158,1 & 176,4 \\
\hline Water & 117,5 & 145,3 & 165,9 & 187,3 & 201,1 \\
\hline Automobile & 96,3 & 121,1 & 148,1 & 171 & 182,8 \\
\hline $\begin{array}{l}\text { Totally in the } \\
\text { national economy }\end{array}$ & 93,9 & 115,2 & 133,5 & 155,1 & 168,5 \\
\hline
\end{tabular}


The problem with the personnel was encounted by automobile transport no less than by railway transport. In the mid-1970-ies from 0.8 to 0.9 million people worked for this kind of transport including about 0.5 million people in the system of the Ministry of transport of Ukraine. Compared to the 1950-ies the number of employees was more than doubled (384 thousand people in 1955). In the mid-1970-ies about $8 \%$ of all employed workers were occupied in automobile transportation [3, 353]. Among them the drivers constituted $62 \%$, maintenance $20 \%$, designers $-4 \%$, employees $-5 \%$, and technical employees - 8\% (Lesyk, 2013).

Kharkov and Kiev automobile and road institutes prepared specialists of the highest category for automobile transport. In 1970 - 1980-ies the material base of higher educational institutions was strengthened, curriculum was improved, manufacturing practice was improved. Although, as the audit showed there was not full realization of the allocated funds for materials, devices, equipment (tires, fuel) because of the lack of control over transit (National economy in USSR, 1966). Despite the difficulties, during $1970-1980$ years in the institutions of higher education there were prepared and sent only to the enterprises of automobile transport of general use about 14 thousand specialists. Specialists of average qualification were prepared at 8 colleges, which sent to automobile transport almost 70 thousand specialists in 1970-1980 years.

During the period of 1960-1980 years out of 1 thousand specialists operating in automobile transport the number of specialists with higher education has increased from 16 to 41 , and with secondary education increased from 42 to 112 people. However, supply of professionals of the automobile transport sector in 1970 accounted only 63\% of general needs (Olsen, Osmundsen, 2003).

Young professionals were reluctant to work at the place of destination. So, in $197347 \%$ of graduates of higher and secondary special institutions did not arrive at the place of work after training (National economy in USSR, 1985).

The staff turnover was high both at automobile transport and at railways. According to the data from January 1, 1971 the number of workers in the sector was 96563 people. During the reporting year 36607 people were hired and 28938 people were dismissed including 17867 people at their own desire and 306 people at the initiative of administration (National economy in USSR, 1971). That shows that the total turnover rate was $25 \%$ and the turnover of workers was even higher $-31 \%$.

Admitting the seriousness of the problem of personnel providing in the automobile transport system more attention was payed to the improvement of social conditions of workers in the industry. For example, in 1970 at the enterprises of the Ministry of Construction and Operation of Highways of USSR there were built and commissioned 26,000 sq meters of living space, 103 showers, 80 rooms for taking meals, 90 rooms for heating workers working outdoors and 33 rooms with washbasins, 77 dressing rooms and 72 mobile carriages. The total number of socio- cultural objects is listed in table 3 (National economy in USSR, 1971).

Table 3

Number of social facilities at motor transport enterprises of USSR as of January 1, 1971

\begin{tabular}{|l|c|c|}
\hline & Number & Number of seats \\
\hline Hostels & 320 & 4894 \\
\hline Canteens & 69 & 2472 \\
\hline Buffets & 30 & 800 \\
\hline Clubs & 28 & 3970 \\
\hline Red corners & 774 & 21670 \\
\hline Recreation & 47 & 1034 \\
\hline Kindergartens & 5 & 265 \\
\hline Clinics & 32 & \\
\hline
\end{tabular}

However, the measures undertaken were clearly inadequate because every year only $3 \%$ of workers out of the list of turn for getting an apartment got accommodation.

Shortcomings and deficiencies in the organization of work, the irresponsibility of individual managers of the various branches led to an increase in number of labour discipline violations, absenteeism, theft, financial fraud. The rate of immergency because of driving vehicles while intoxicated, violation of road traffic and public regulations by the employees of the automobile transportation enterprises was growing (National economy in USSR, 1985).

Staff problems have existed in water transport where the number of employees was growing. So, the number of employees of the fleet of the Dnieper basin in 1970-ies was more than 26 thousand people and in 1980-ies it exceeded 30 thousand people. In the early 1980 -ies the scope of parttime professions on the transport fleet expanded. In 19801981years the crews of all high-speed vessels started to work part-time jobs. The crews of more than 1000 vessels worked this way and it was about $91 \%$ of the total river fleet.

Wage of workers of river transport was relatively high. In 1980 it was $11 \%$ higher than the average wage in the transport industry and $21 \%$ higher than the average wage for the national economy. However, as in the whole transport sector, social conditions of workers were unsatisfactory. At the beginning of 1959 in the Dnipro shipping company there were 3,000 families, which needed better housing conditions, but funds for housing construction were almost not allocated. Only later in 1960 the situation was improved and it was spent 38.5 million rubles for housing construction or $10 \%$ of total capital investment. In general, during 1971-1983 years it was built 59 houses with a total area of over 190 thousand square meters, with 2 hospitals, 6 kindergartens for workers of river transport of the Republic (Lesyk, 2013).

The problem of personnel at the aviation enterprises of civil aviation was urgent where in the mid-1970-ies more than 39 thousand people were working [33, 3]. Like the other kinds of transport, civil aviation suffered lack of qualified staff - the engineering team was staffed by $86 \%$, technical - by $87 \%$. Therefore, the airline took 
measures to improve recruitment and retention. Positive experiences in 1970-ies was acquired in the Simferopol united squadron where for three years of the 9th fiveyear plan there were re-trained in the class and the category specialists in all fields - 346 people, including flight crews - 116 people. At this airline $62 \%$ of senior management personnel had work experience more than 3 years. For 3 years the team added 134 young professionals (National economy in USSR, (1971).

The industry's share of young specialists decreased. In 1970-ies 900-950 young professionals were sent to work annually but in 1979 only 694 graduates of higher educational institutions came to work to the industry, thus practically we didn't add new pilots - there are totally only 46 people. Labour discipline among the workers was low. In 1971 the number of personnel misconduct has increased, 2829 against 2663 in 1970 . Only in 1979 30 people were summarily dismissed, 25 of them for truancy, 3 men for drinking alcohol during working hours. In addition, 65 people were demoted, 25 of them were pilots transferred to ground work. In $197933.9 \%$ of command aircrew was dismissed for the deficiencies in the discipline (Central State Arheve of Higher Organs of Power and Management, (1970).

Attempts were made to improve the situation with training. Funds were allocated for the creation of visual aids, equipment, instructional navigation cabinets. At the factories of the Ministry of Aviation Industry, at the training divisions, at the aviation-technical bases there were held 885 re-training of specialists for work on the new aircraft (Lesyk, 2013).
There was a high turnover of staff. Although in general, concerning main professions it decreased slightly from $3.9 \%$ in 1976 to $3.8 \%$ in 1979 , but also among specialists from $9.2 \%$ to $8.1 \%$. However, in many departments of civil aviation of the republic staff turnover remained high. The high turnover of key specialists took place in Boryspil united squadron - $13.5 \%$, in Odessa - $13.3 \%$ and in Nikolaevsk - $11.9 \%$.

\section{Conclusion}

In the condition of reconstruction and technical re-equipment of all transport industries the problem of providing the transport sector with the personnel is still quite urgent. Insight into the history of solving staffing problems of the transportation sector brings best practices into morden stage of its development.

It is found out that lack of trained skilled workers in 1960 - 1980-ies was supplemented by the common to all transport sectors negative factors, which caused a significant turnover of staff, not full complement of many transport links. Among these factors were low wages, unsatisfactory level of working conditions, and lack of basic social conditions, which are primarily connected with housing problems.

Measures for the solution of the problems of personnel and human resources of the transport complex are taken. They were such as opening new and improving existing educational institutions of all levels, re-training of personnel directly at the workforce. We consider these measures to be best practices of the studied period in the transport sector development.

\section{References}

Lesyk, S.M. (2013). Pidgotovka ta vykorystannia kvalifikovanyh inzhenerno-tehnichnyh kadtiv zaliznychnoho transportu (1945-1980 roky). Visnyk Cherkaskoho universytetu. Seria: Istorychni nauky, p. $72-81$.

National economy in USSR in (1966). Kyiv: Derzhstatvydav, p. 88.

Olsen, T.E., Osmundsen, P. (2003). Spillovers and international competition for investments. Journal of International Economics, Vol. 59, issue 1, p. 211-238.

National economy in USSR (1971). Kyiv: Statystyka, p. 113.

National economy in USSR (1985). Kyiv: Tehnika, p. 828-289.

History of rail transport in the Soviet Union, Vol. 3. 1945-1991. (1970). Part 7. Retrieved from: https: //wiki.nashtransport.ru

Central State Arheve of Higher Organs of Power and Management. (1970) F. 4924, d. 19, p. 67.

\section{Анатолий ГОРБАНЬ}

\section{ПРОБЛЕМАТИКА КАДРОВОГО ОБЕСПЕЧЕНИЯ ТРАНСПОРТНОГО КОМПЛЕКСА УКРАИН- СКОЙ РСР В 1960-1980-х ГОДАХ}

Анотация. В статье рассматриваются проблемы кадрового обеспечения отраслей транспортного комплекса СССР в период радикальной технической реконструкции и быстрого развития (1960-1980 гг). Основная цель этой статьи состоит в том, чтобы проанализировать особенности развития кадрового потенциала транспортного комплекса Украинской ССР в годы интенсивного развития транспортного сектора, выяснить социальную составляющую мер по повышению эффективности транспортных сетей. Методология. В этой статье был использован метод анализа, а именно был проанализирован качественный состав персонала, подготовка квалифицированных рабочих в учебных заведениях и других форм повышения личных навыков 
работников транспорта. Причины текучести кадров и низкой трудовой дисциплины изучаются. Практическая реализация. В данной статье приведены все возможности для современного транспортного комплекса Украины, как быть успешным и конкурентоспособным на рынке. Исторический фон этой статьи может быть очень полезным для нынешних руководителей транспортной системы. Результаты. Автор делает общий вывод, что основными причинами текучести кадров в транспортных отраслях являются низкая заработная плата, условия труда и отсутствие помещений для персонала. Обозначены социальные и практические меры по повышению эффективности работы с персоналом всех отраслей транспортной системы. 